\title{
OPEN 2020 COVID-19 lockdown and the impacts on air quality with emphasis on urban, suburban and rural zones
}

\author{
Klara Slezakova ${ }^{\boxplus}$ \& Maria Carmo Pereira
}

Air quality improvements pollution changes due to COVID-19 restrictions have been reported for many urban developments and large metropolitan areas, but the respective impacts at rural and remote zones are less frequently analysed. This study evaluated air pollution changes across all Portugal (68 stations) considering all urban, suburban and rural zones. $\mathrm{PM}_{10}, \mathrm{PM}_{2.5}, \mathrm{NO}_{2}, \mathrm{SO}_{2}$, ozone was analysed in pre-, during, and post-lockdown period (January-May 2020) and for a comparison also in 2019. $\mathrm{NO}_{2}$ was the most reduced pollutant in 2020, which coincided with decreased traffic. Significant drop (15-71\%) of traffic related $\mathrm{NO}_{2}$ was observed specifically during lockdown period, being $55 \%$ for the largest and most populated region in country. PM was affected to a lesser degree (with substantial differences found for largely populated areas (Lisbon region 30\%; North region, up to 49\%); during lockdown traffic-related PM dropped $10-70 \%$. $\mathrm{PM}_{10}$ daily limit was exceeded $50 \%$ less in 2020 , with $80 \%$ of exceedances before lockdown period. $\mathrm{SO}_{2}$ decreased by $35 \%$, due to suspended industrial productions, whereas ozone concentrations slightly (though not significantly) increased (83 vs. $80 \mu \mathrm{g} \mathrm{m}^{-3}$ ).

In January 2020 the World Health Organization (WHO) declared a global health emergency because of the novel coronavirus disease (COVID-19) that has been uncontrollably spreading all over the world ${ }^{1}$. Since then, the pandemic has affected our whole society; WHO has registered 123 million cases worldwide with a total of 2.7 million mortalities ${ }^{2}$. To limit the spread of pandemic, governments in countries around the world have imposed various restrictions, which led to reduction of people movement, decrease in transport (road and aviation), and even suspended industrial activities ${ }^{3}$. While COVID-19 has caused many adverse changes to our society and economies ${ }^{4,5}$ and even to environment (in a form of newly created medical waste ${ }^{6}$ ), some studies have emphasized a possible improvement of the state of the environment ${ }^{7}$. People confinement, restricted public transport and ceased airlines international flights have also resulted in changes in air pollutant emissions, with information for megacities (Rio de Janeiro and Sao Paolo ${ }^{8,9}$; and highly populated urban zones and cities ${ }^{10-17}$. On more global scale, during the COVID-19 pandemic, $\mathrm{PM}_{2.5}$ dropped approximately $12 \%$ across the most polluted cities worldwide, with the greatest reduction in capitals of America, Asia and Africa ${ }^{18}$. While the current studies even show that there might be causality between air pollution and COVID-19 infection spread ${ }^{19,20}$, the main focus of the COVID air pollution studies is typically on large and densely populated urban areas ${ }^{21-23}$ during relatively a short (or part of) period of lockdowns. The changes in air pollution trends during the lockdown in rural or remote places have been reported to much lesser degree. Ceased air and road transport and restricted human movements during the lockdowns allow for a unique situation for prediction of modelling and visualization of potential air pollution mitigation scenarios. However, the complete perspective requires first information on air pollution changes not only in urban but also in rural and remote areas. This work thus evaluates the air pollution evolution ( $\mathrm{PM}_{10}, \mathrm{PM}_{2.5}, \mathrm{NO}_{2}, \mathrm{SO}_{2}$, ozone) in pre-, during and post-lockdown period (January 1-May 2020) in whole Portuguese territory (continent and islands; 7 regions) considering all rural, suburban, urban zones. To provide wider context, air pollution data are assessed and also compared to the same period of the previous year. 


\begin{tabular}{|c|c|c|c|c|c|c|c|c|c|c|}
\hline \multirow[b]{3}{*}{ Region } & \multirow{3}{*}{$\begin{array}{l}\text { Stations } \\
\mathbf{n}(\%)\end{array}$} & \multicolumn{9}{|l|}{\begin{tabular}{|l|} 
Type \\
n (\%)
\end{tabular}} \\
\hline & & \multicolumn{3}{|l|}{ Rural } & \multicolumn{3}{|l|}{ Suburban } & \multicolumn{3}{|l|}{ Urban } \\
\hline & & \begin{tabular}{|l|} 
Background \\
\end{tabular} & Traffic & Industrial & Background & Traffic & Industrial & Background & Traffic & Industrial \\
\hline North & $22(32)^{\mathrm{a}}$ & $3(14)^{b}$ & - & - & $6(27)$ & - & $1(5)$ & $5(23)$ & $6(27)$ & $1(5)$ \\
\hline Centre & $9(13)$ & $4(44)$ & - & - & $2(22)$ & - & - & $1(11)$ & $2(22)$ & \\
\hline Lisbon TV & $24(35)$ & $3(13)$ & - & - & - & - & $1(4)$ & $13(54)$ & $5(21)$ & $2(8)$ \\
\hline Alentejo & $5(7)$ & $2(40)$ & - & $1(20)$ & $1(20)$ & - & - & - & - & $1(20)$ \\
\hline Algarve & $4(6)$ & $1(25)$ & - & - & - & - & - & $2(50)$ & $1(25)$ & - \\
\hline Madeira & $3(4)$ & $1(33)$ & - & - & - & - & - & $1(33)$ & $1(33)$ & - \\
\hline Azores & $1(2)$ & 1 & - & - & - & - & - & - & - & - \\
\hline Total & 68 & 15 & - & 1 & 9 & - & 2 & 22 & 15 & 4 \\
\hline
\end{tabular}

Table 1. Air pollution monitoring network in Portugal: summary of zone- and emission influence-specific monitoring sites in each region. ${ }^{a} \%$ considering the whole territory. ${ }^{b}$ Indicated $\%$ is estimated considering of abundance of a station/type in each district. Depending on the density and distribution of buildings, stations are classified as the folloing: rural—all other areas; suburban — largely built-up; urban area urbancontinuously built-up urban area; background stations-pollution levels are representative of the average exposure of the general population or vegetation; traffic-situated in a close proximity to a single major road; industrial stations-situated in close proximity to an industrial area or an industrial source ${ }^{27}$.

\section{Materials and methods}

Air quality network. The assessment of air quality in Portugal is conducted by the Portuguese Environment Agency (APA). The air quality measurement stations are managed by the Regional Development and Coordination Commissions (CCDR) of the region in which they operate. The classification of seven regions of Portuguese territory (five for the continent-North, Centre, Lisbon and Tejo Valley (Lisbon TV), Alentejo, Algarve; two for islands-Madeira, and Azores) was also adopted for this work (Supplementary Table 1S of the Supplementary Information). Each monitoring station is characterized based on its type of agglomeration zone (rural, suburban or urban). The predominant influence of anthropogenic emissions further determines sub-type of each site as traffic, industrial or background. The air pollution data are measured continuously at all monitoring stations from which they are transmitted, in almost real time, to regional "centres". From these they are communicated to the central information system of QualAr database ${ }^{24}$, based at $\mathrm{APA}^{25}$. The data are then made available to the public through QualAr portal ${ }^{26}$. Table 1 and Supplementary Fig. $1 S$ of the Supplementary Information summarized the characteristics of monitoring stations per each district. All 68 monitoring stations were considered in this work.

Air pollution data. The state of emergency due to the spread of COVID-19 pandemic was enforced from 19 March to 2 May 2020, with a strict consequent phase until 1 June $2020^{28}$. Up to this date, various limitations are still applied in Portugal (among other restrictions for public gatherings, obligatory use of masks in enclosed public spaces such as transport, shops or public offices, restricted working hours for bars and restaurants, etc.). Air pollution data were thus retrieved from the public QualAr database for all five months of 2020, specifically between January 1 and May 31. The data from the same period of the previous year 2019 were also considered for the comparison.

All air pollutants available online by QualAr were considered, namely, $\mathrm{PM}_{10}, \mathrm{PM}_{2.5}, \mathrm{O}_{3}, \mathrm{NO}_{2}$, and $\mathrm{SO}_{2}$. For particles, daily $(24 \mathrm{~h})$ average concentrations are published whereas it was maximum hourly average for $\mathrm{O}_{3}$, $\mathrm{NO}_{2}$, and $\mathrm{SO}_{2}$. Air quality standards in Portugal ${ }^{29,30}$ are based on the existent European legislation govern by Directive 2008/50/EU ${ }^{31}$; for a reader convenience the respective standards and the limit values are summarized in Supplementary Table 2S).

Traffic data. There are 15 principal motorways in continental Portugal. As there is no public database that would provide summarized information on number of vehicles in Portugal, the existing data regarding traffic counts were retrieved from available annual reports of the company ${ }^{32,33}$ that ensures the majority operations of motorways system in the country. Additional information was then retrieved from public reports and research projects, published on web portals of city halls of Metropolitan Areas of Lisbon and of Oporto ${ }^{34-36}$ (Supplementary Table 3S). Data on activity across various sectors was obtained from Google LLC ${ }^{37}$.

Statistical analysis. All statistical tests for this study were performed by SPSS (IBM SPSS Statistics 26) and Microsoft Excel 2013 (Microsoft Corporation). Medians and means were compared through the non-parametric Mann-Whitney U test as the obtained data did not display normal distributions (confirmed by Shapiro-Wilk's test). Statistical significance was set as $p<0.05$. 


\section{Results and discussion}

Air pollution monitoring network. As shown in Table 1 and Supplementary Fig. 1S, most of the monitoring sites were situated in the districts of North and Lisbon TV. These two regions accounted for $67 \%$ of all monitoring stations while they compose approximately $35 \%$ of the Portuguese territory area (Supplementary Table 1S). Centre region accounted for $13 \%$ of the monitoring sites, whereas in Alentejo (30\% of the total area) and Algarve district (5\%) there are 7 and $6 \%$ of the monitoring stations, respectively. Portuguese islands represent a much smaller area $(\sim 3.5 \%)$ and hence a limited amount of monitoring stations $(6 \%)$.

Evaluating the zone impact of each station (i.e. rural vs. suburban and urban) it is noteworthy that monitoring stations in urban zones are predominantly situated in North and Lisbon TV regions (47\%). This is understandable considering that these two regions contain the two largest Metropolitan Areas in the country (of Oporto and Lisbon, respectively), with approximately $45 \%$ of the total Portuguese population (17 and $28 \%$ for area, respectively, in 2019) ${ }^{38}$. In fact, monitoring sites of urban zones account for 55 and $83 \%$ in each of these regions, respectively. In addition, the North was the region with the highest number of monitoring sites in suburban zones $(10 \%)$, whereas the monitoring stations for rural areas are relatively uniformly distributed among all regions (4-6\% in North, Centre, Lisbon TV and Alentejo, $1-3 \%$ in the remaining regions).

Evaluating the specific emission sources, $40 \%$ of all monitoring sites with traffic influence were situated in Northern monitoring network where it consists $28 \%$ of all the district stations. In addition, $65 \%$ of all background sites were situated in the most populated regions of Lisbon TV (67\% the district stations) and in North (63\%). On the national perspective, monitoring stations under influence of industrial emissions were the least existent (10\%), being uniformly distributed between North, Lisbon TV and Alentejo region.

Traffic data. Evaluation of daily average traffic (on motorways) in $2018-2020^{32,33}$ is shown in Supplementary Fig. 2S. It is clear that quarterly (Q1-Q4) evolution trends of traffic were the rather same between 2018 and 2019, with the highest peak always observed during the summer months, i.e. 3rd quarter (Q3, 25,530 vs. 25,916 vehicles day ${ }^{-1}$, respectively). Similarly, this trend also occurred in 2020 (Q3 peaking with 22,060 vehicles $\mathrm{day}^{-1}$ ). Furthermore, when compared to previous year, in 2019 traffic showed a consistent growth of 3.7\%, for each quarter as the following, 5.6\% for Q1, 6.3\% for Q2, 1.5\% for Q3 and 2.1\% for Q4. It noteworthy, that heavy vehicle traffic showed a higher growth rate (4.5\%) than light vehicles $(3.6 \%)$. In agreement, additional data showed that road transport supply (for transport of passengers) increased to 29.4 billion seats-km, with $83.1 \%$ of its total being made available on regular transport ${ }^{35}$. The number of national transport services increased by 9.2\% to 20.5 million, while 543.1 million passengers were carried, representing an increase of $5.5 \%$ compared to the previous year of $2018^{35}$.

On the contrary, the overall amount of traffic decreased during all Q1-Q4 of 2020. During the first quarter of 2020 the average daily traffic was 12\% lower in a comparison with 2019 and 7\% lower when compared with 2018 (Supplementary Fig. 2S). Mobility data (Supplementary Fig. 3S) that is based on historical geo-localization of mobile phones with activated GPS showed that people spent up to 30\% more time at home during March-May $2020^{37}$. The mobility to work and the use of public transportation significantly decreased (up to 66 and $\left.78 \%\right)^{37}$. In addition, due to the restrictions associated with COVID-19, retail and recreational mobility were strongly reduced (up to 76\%) as well as visits to grocery and pharmacy shops (up to $-46 \%$ ) $^{37}$. Specifically, for the Q2 of 2020 the traffic reduction was 46 and $49 \%$ when compared with the previous years and it represented $32 \%$ decrease (when compared with Q1 of 2020; Supplementary Fig. 2S). Furthermore, the available data show that light vehicles were more impacted by the traffic reductions than heavy vehicles, with the respective decrease of 12 and $2 \%$ respectively ${ }^{33}$; in 2020 heavy vehicles accounted for $7.2 \%$ of the traffic (vs. $5.7 \%$ in 2019 , Supplementary Fig. 4S).

Air pollution data, 2019 vs. 2020. Particulate matter. The levels of air pollutants, namely $\mathrm{PM}_{10}, \mathrm{PM}_{2.5}$, $\mathrm{NO}_{2}, \mathrm{SO}_{2}$ and $\mathrm{O}_{3}$ in seven Portuguese regions are summarized Fig. 1, which show the statistics across all monitoring stations for the three types of zoning (rural-urban). Specifically, in 2019 daily levels of $\mathrm{PM}_{10}$ measured at 68 monitoring stations demonstrated large variations of the obtained data (Fig. 1a), with detailed descriptive statistics summarized in Supplementary Table $4 \mathrm{~S}$. Average daily $\mathrm{PM}_{10}$ means were between 12 and $20 \mu \mathrm{g} \mathrm{m} \mathrm{m}^{-3}(\mathrm{ab}-$ solute range 1-74 $\left.\mu \mathrm{g} \mathrm{m}^{-3}\right)$ in rural zone of the five regions of Continental Portugal, $18-21 \mu \mathrm{g} \mathrm{m}^{-3}\left(2-82 \mu \mathrm{g} \mathrm{m}^{-3}\right)$ in suburban zones and $20-24 \mu \mathrm{g} \mathrm{m}^{-3}\left(1-116 \mu \mathrm{g} \mathrm{m}^{-3}\right)$ in urban ones. Regions of Portuguese islands showed lower concentrations, especially at rural zones with the corresponding means of $11 \mu \mathrm{g} \mathrm{m}^{-3}$ (Madeira, range $2-71 \mu \mathrm{g} \mathrm{m}^{-3}$ ) and $7 \mu \mathrm{g} \mathrm{m}^{-3}$ at Azores $\left(2-17 \mu \mathrm{g} \mathrm{m}^{-3}\right)$. These results demonstrated that for all 7 regions daily $\mathrm{PM}_{10}$ concentrations were the lowest at rural zones being significantly $(p<0.05)$ different (approximately $15 \%$ in Algarve-60\% for North) that the respective means at urban zones (or suburban for Alentejo). Regarding the EU limits daily $\left(50 \mu \mathrm{g} \mathrm{m}^{-3}\right)$, for urban zones the exceedances were observed in $30 \%$ of the rural stations, two in Centre, one in Lisbon TV, one in Madeira, one in Alentejo (the respective monitoring station is with industrial influence due to the industrial power plan). It is though necessary to point out that EU legislation stipulates a tolerance of exceedance 35 per year and in that regard all the monitoring stations fulfilled the conditions as the registered exceedances occurred 1-7 times per the same station (Supplementary Table 5S). Furthermore, it is necessary to enhance that the raw data were considered in this work and the possibility of subtracting contributions to the measured concentrations from natural sources and winter road sanding/salting has not been considered. In all the other regions (North, Algarve and Azores islands), no concentrations higher than daily limit were registered in rural zones. On the contrary, suburban and urban zones of Portugal exhibited exceeded the daily limits in all regions/zones. These were especially high for North (total of 57) and in Lisbon TV (64), which were the regions with the higher number of stations. In Centre, the limits were approximately 3 times less ( 21 


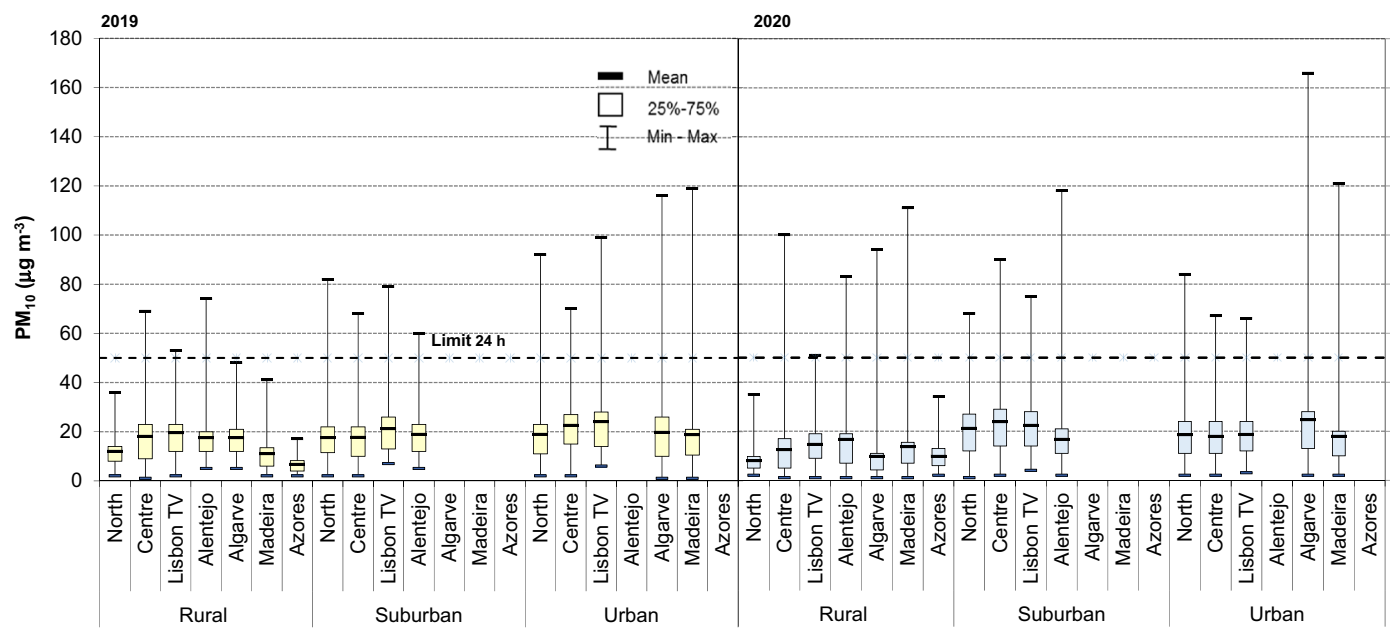

a)

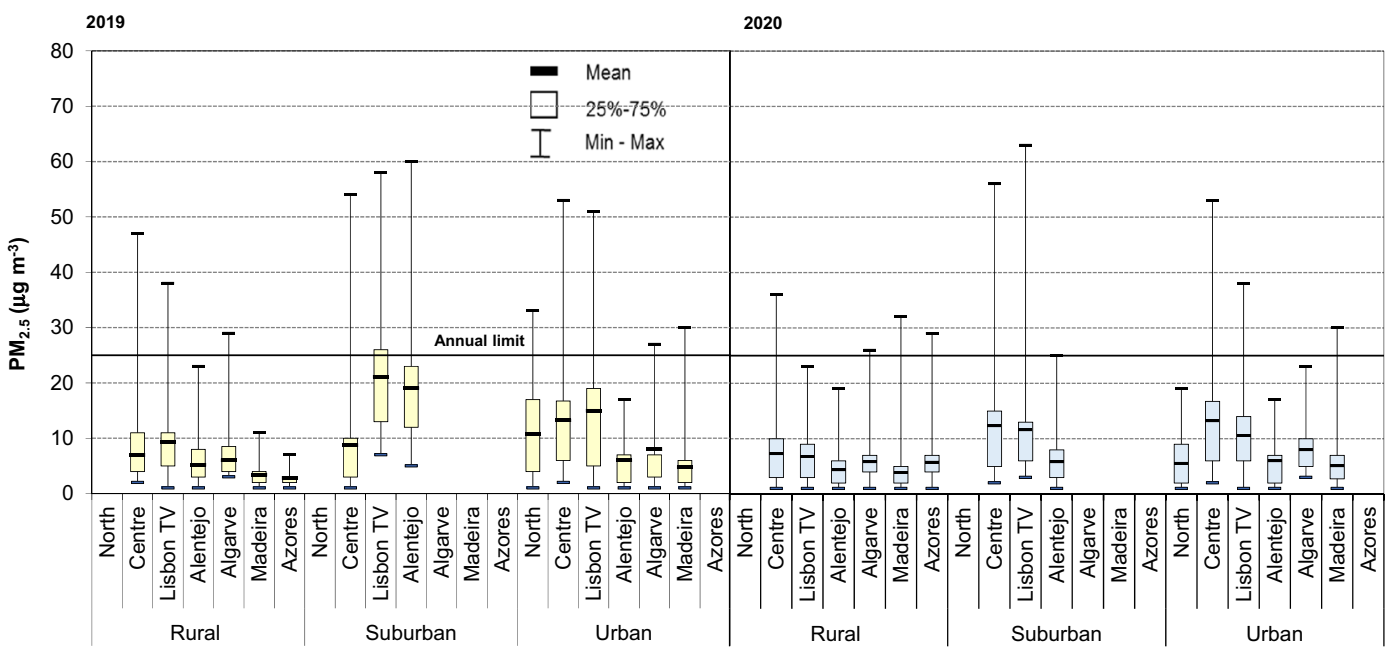

b)

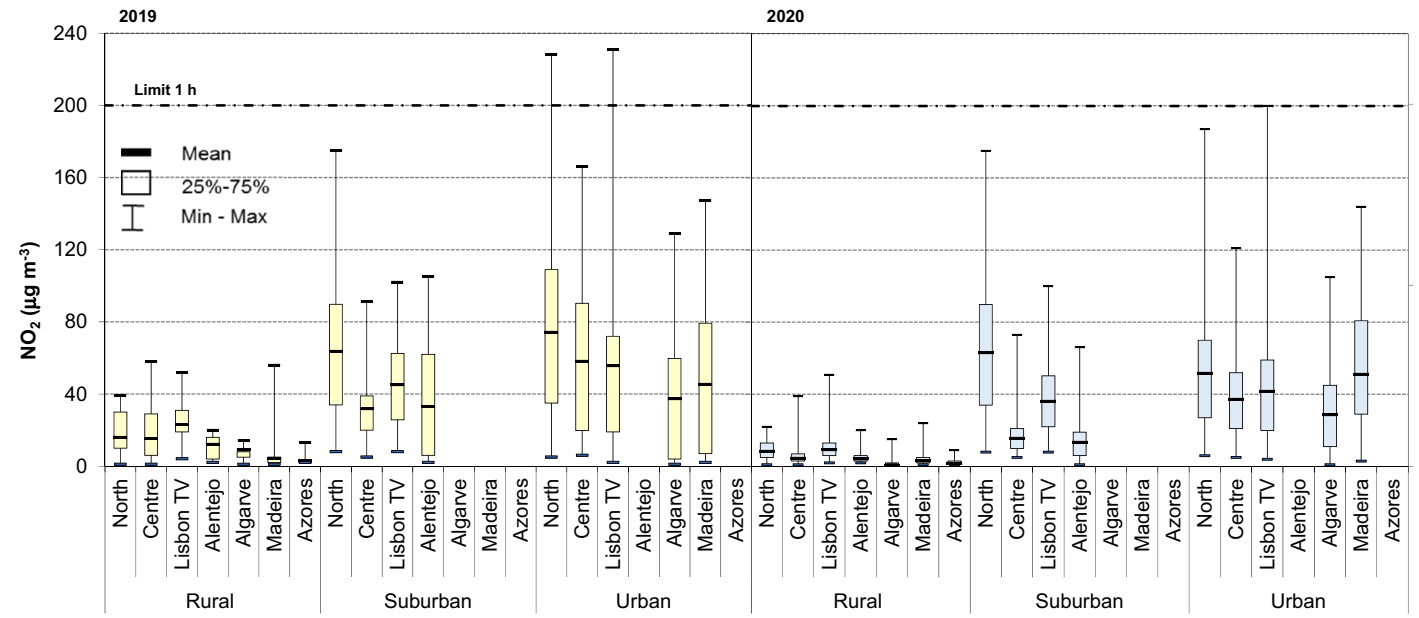

c)

Figure 1. Concentrations of particulate and gaseous air pollutants (closed square, median; open square, 25-75\%, and range) in (January-May) 2019 and 2020 in Portugal, (a) $\mathrm{PM}_{10} ;$ (b) $\mathrm{PM}_{2.5} ;$ (c) $\mathrm{NO}_{2}$; (d) $\mathrm{SO}_{2}$; and (e) $\mathrm{O}_{3}$. Notes: Horizontal dashed lines represent the $1 \mathrm{~h}$ and $24 \mathrm{~h}$ standards as defined in Directive 2008/50/EU $\mathrm{E}^{31}$. For $\mathrm{PM}_{2.5}$ horizontal line represents annual limit. Distributions of each pollutant were significantly different $(p<0.05)$ across the three zones and emissions sources. The concentrations of PM are expressed as $24 \mathrm{~h}$ averages whereas the gaseous pollutants are expressed as $1 \mathrm{~h}$ maxima. For better visualization vertical axis y uses different scale. 

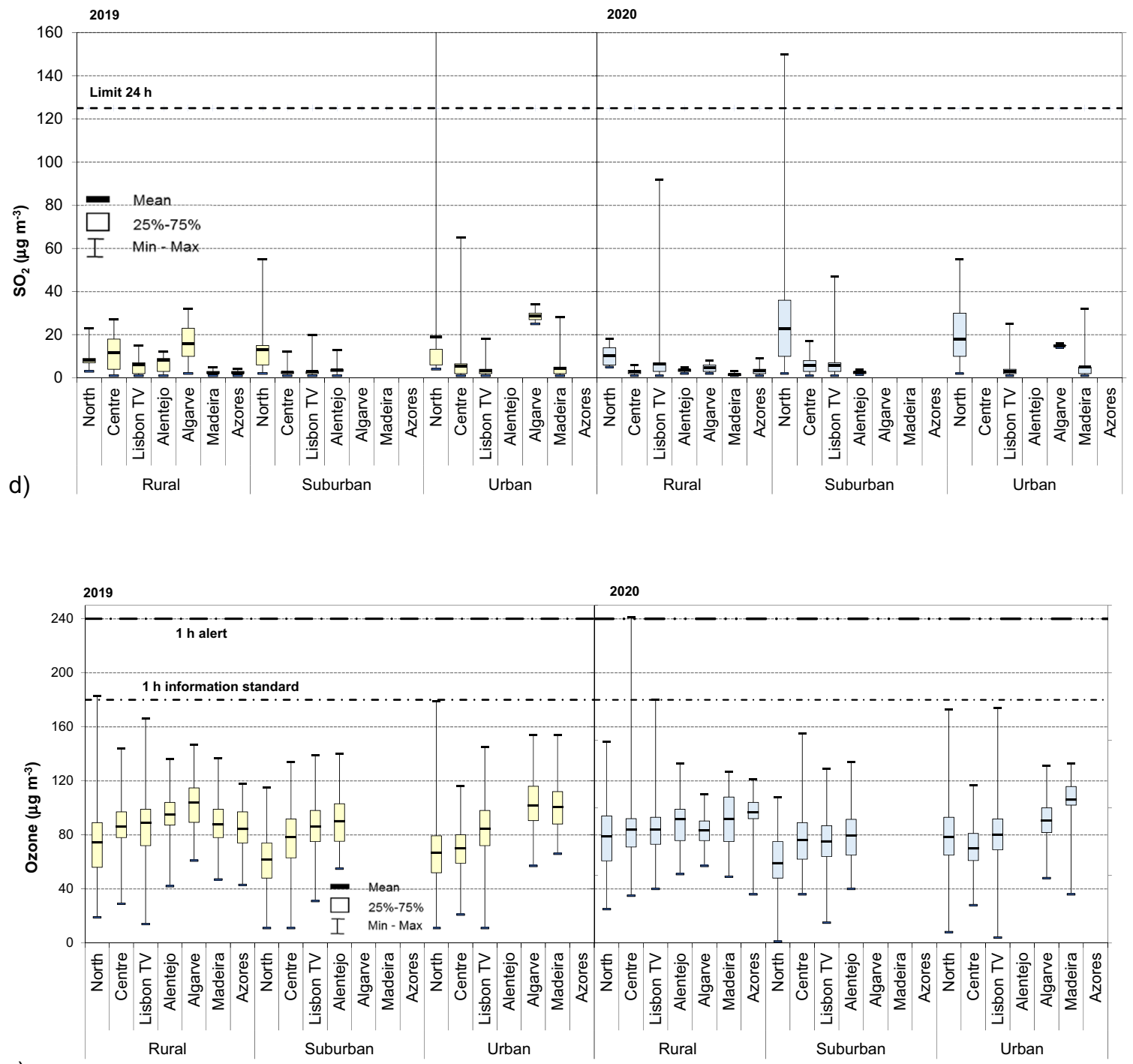

e)

Figure 1. (continued)

times), whereas in Alentejo and Algarve the exceedance were even less frequent (6 and 12 times, respectively); in all stations the margin of tolerance ( 35 exceedance) fulfilled in all monitoring sites.

In 2020 the levels of $\mathrm{PM}_{10}$ (Fig. 1a, Supplementary Table 5S) were slightly lower in a comparison with the previous year. Daily means of $\mathrm{PM}_{10}$ for Continental Portugal were observed as the following, $8 \mu \mathrm{g} \mathrm{m}^{-3}$ (North) to $17 \mu \mathrm{g} \mathrm{m}^{-3}$ (Algarve) in rural zones, $17 \mu \mathrm{g} \mathrm{m}^{-3}$ (Alentejo) - $24 \mu \mathrm{g} \mathrm{m}^{-3}$ (Centre) in suburban one, and $17 \mu \mathrm{g} \mathrm{m}^{-3}$ (North) and $25 \mu \mathrm{g} \mathrm{m}^{-3}$ (Algarve) for urban zones. These results showed that in rural zones, $\mathrm{PM}_{10}$ concentrations

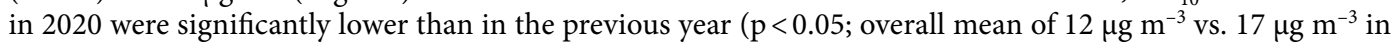
2020 ), with the respective percentage being between $30 \%$ (Lisbon TV) and $80 \%$ in Alentejo. In urban zones, the respective PM were lower in 2020 only in Centre and Lisbon TV regions ( 30\%), whereas PM no differences were observed in North and Alentejo region. Within the urban areas, ambient air pollution is typically dominated by motor vehicles traffic, but due to the variables such as number of junctions, distance to roadways, traffic flows, surrounding road length, and others the respective pollution levels may vary greatly ${ }^{39-41}$. It is assumed that the lesser traffic in 2020 (Supplementary Fig. 2S) might be the cause for the lower PM levels in some of the urban zones.

The analysis of $\mathrm{PM}_{10}$ levels across the urban zones with traffic emissions specifically (i.e. 22 monitoring urban-traffic sites) showed that in terms of monthly evolution (Fig. 2a) $\mathrm{PM}_{10}$ started to decrease in February 2020 (mainly North and Centre), with the minimal levels (in all regions) observed in April (when the state of emergency was still implemented) and then increased in May (state of emergency ended).The examples of temporal variations of the pollutants are shown in Supplementary Fig. 5S-7S. During the lockdown period, $\mathrm{PM}_{10}$ showed a decline (for all the regions), having the highest reductions in the Centre region (61\%). The reduced vehicular movement, limited industrial and construction activities could be responsible for the decline in $\mathrm{PM}_{10}$ emissions ${ }^{42}$.

When comparing concentrations at urban traffic sites between the both years (Fig. 2b), the largest drops of $\mathrm{PM}_{10}$ were observed, as expected in month of April (10-70\% in Madeira and Algarve) but also February (up to $70 \%$ in North). These data may are in agreement with the road transport trend that shows overall lower traffic in 

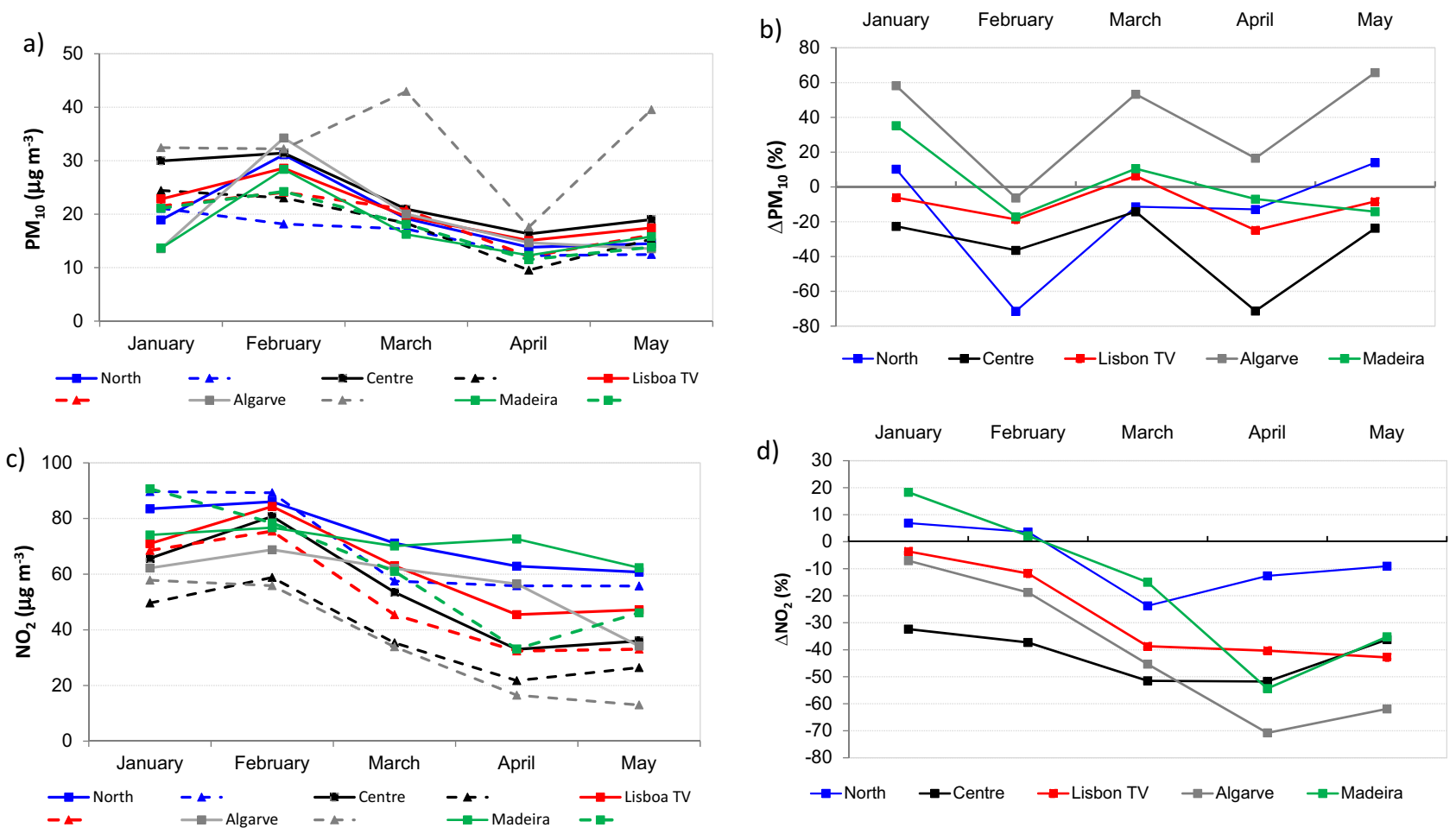

Figure 2. Assessment of traffic related pollution of $\mathrm{PM}_{10}$ and $\mathrm{NO}_{2},(\mathbf{a}),(\mathbf{c})$ monthly profiles (January-May) in 2019 and 2020; (b) and (d) representations of pollutant concentration changes in 2020 vs. 2019. Dashed lines represent 2020 values whereas continuous lines represent levels in 2019. Monthly means were estimated across $22 \mathrm{urban} /$ traffic monitoring stations.

2020 (during the first and second trimester; Supplementary Fig. 2S-3S). Furthermore, it needs to emphasized that though in urban areas, $\mathrm{PM}_{10}$ is strongly affected by local emissions (e.g., traffic including resuspension, building works, industry, etc.), meteorology is a significant parameter for pollutant levels and dispersion. Therefore, analysis of meteorological parameters (temperature, precipitation, wind directions and intensity, pressure distribution) would be precious in order to assess the role of the meteorology on the observed concentration changes and the impact of the emission reductions. In general, the obtained results are in agreement with study by Gama et al. ${ }^{43}$ who reported $\mathrm{PM}_{10}$ levels at selected sites across Portugal for that respective period. Authors reported overall drop of $18 \%$ (a mean reduction of about $16 \%$ urban background sites and up to $27 \%$ in traffic ones). Furthermore, though not distinguishing between different regions, the authors also reported $>20 \%$ reduction for $\mathrm{PM}_{10}$ at rural zones. Thus, as the contribution of traffic emissions decreased on the local and regional (with restrictions taking place in majority of European countries), $\mathrm{PM}_{10}$ changes at rural site might have been affected due to the lesser transport of long-distance emissions, as reported elsewhere ${ }^{44}$.

On the contrary, in suburban sites, in $2020 \mathrm{PM}_{10}$ (Fig. 1) were higher (overall $21 \mu \mathrm{g} \mathrm{m}^{-3} \mathrm{vs.} 20 \mu \mathrm{g} \mathrm{m}^{-3}$ in 2019), though these differences were not statistically significant. Specifically, the highest increases were observed in Centre (30\% more in 2020) in North (20\%) regions. However, Centre region consists only of 2 suburban stations and thus the respective results need to be implied carefully, possibly over longer time context. Though North region contained $77 \%$ of the suburban sites, they were background type (Table 1). In addition, on European level road transport contributes only $\sim 11 \%$ of $\mathrm{PM}$ in $\mathrm{EU}$, the main sources of $\mathrm{PM}_{10}{ }^{27}$ are commercial, institutional and household sector (39\%) and industrial processes (20\%), which could be linked with the unchanged trends of $\mathrm{PM}$ in the suburban zones. In terms of $\mathrm{PM}_{10}$ legislation, $24 \mathrm{~h}$ limit was exceeded in all three types of zones in 2020. However, majority of the exceedances were observed in urban zones (87\%, Supplementary Table 5S) and furthermore, $80 \%$ of these exceedances occurred in January and February (i.e., before the state emergency regulations took place). In addition, it is necessary to highlight that in 2020 , for the respective period of 5 months, $\mathrm{PM}_{10}$ daily limits were exceeded approximately 50\% less (107 vs. 218 in 2019). Thus, the results indicate that PM concentrations were positively influenced in 2020, most likely also by the lower vehicle road traffic. It is necessary to highlight that Algarve was the only region that in 2020 exhibited very different evolution of PM at urban traffic sites (and higher concentrations at urban traffic sites during all 5 months of 2020) from the rest of the territory (Fig. 2a). While the previous works emphasized the impacts of long-range transport of mineral dust from North Africa with high frequency and prevalence namely in southern parts of Portugal ${ }^{45,46}$ it needs to be highlighted that these data (urban traffic in Algarve region) are based on 1 monitoring station (Table 1). Thus, these values will need to be confirmed when the final registry of APA is released.

Concerning the fine fraction, 2019 average daily $\mathrm{PM}_{2.5}$ means (Fig. 1b) were between 5 and $9 \mu \mathrm{g} \mathrm{m}^{-3}$ (absolute range $\left.1-47 \mu \mathrm{g} \mathrm{m}^{-3}\right)$ in rural zone of the five regions of the Continental Portugal, 9-21 $\mu \mathrm{g} \mathrm{m}^{-3}\left(1-60 \mu \mathrm{g} \mathrm{m}^{-3}\right)$ in suburban zones and 5-15 $\mu \mathrm{g} \mathrm{m}^{-3}\left(1-53 \mu \mathrm{g} \mathrm{m}^{-3}\right)$ in urban ones. In agreement with $\mathrm{PM}_{10}$, these results demonstrated 
that for all 7 regions daily $\mathrm{PM}_{2.5}$ concentrations were the lowest at rural zones being significantly $(p<0.05)$ different (approximately 15\% in Alentejo-90\% for Centre) than the respective concentration at urban zones. In 2019, for the considering period, the overall mean $\left(7 \mu \mathrm{g} \mathrm{m}^{-3}\right.$ across 68 monitoring stations) was well below the annual target (Supplementary Table 1S), though these results need to be implicated carefully, once the considered work of this study included 5 months (i.e., $42 \%$ of the calendar time). Worldwide, Portugal is among the countries with the better air quality in terms of $\mathrm{PM}_{2.5}{ }^{47}$; in 2017 it ranked as 7 th country in European Union with the lowest $\mathrm{PM}_{2.5}$ across 27 members ${ }^{27}$. Furthermore, it is noteworthy that for fine fraction, out of the three different zones, suburban areas presented the highest $\mathrm{PM}_{2.5}$ (overall mean of $16 \mu \mathrm{g} \mathrm{m}^{-3}$ ) with $25-73 \%$ higher concentrations than the respective levels (of the each region) at the rural zones. Still, the exposure concentration obligation $\left(20 \mu \mathrm{g} \mathrm{m}^{-3}\right.$; calculated based on the levels of $\mathrm{PM}_{2.5}$ at suburban and urban background sites) is typically obliged ${ }^{27,31}$.

In 2020, the lowest $\mathrm{PM}_{2.5}$ concentrations were observed in rural zones where they ranged between $4 \mu \mathrm{g} \mathrm{m}^{-3}$ (Algarve) and $7 \mu \mathrm{g} \mathrm{m}^{-3}$ (Centre and Lisbon TV). The corresponding levels in suburban and urban areas were $30-90 \%$ higher with, respectively, overall means of $6 \mu \mathrm{g} \mathrm{m}^{-3}$ (Alentejo) and $12 \mu \mathrm{g} \mathrm{m}^{-3}$ (Lisbon TV) in suburban and 5-13 $\mathrm{g} \mathrm{m}^{-3}$ (Madeira and Centre region) in urban zones. In comparison with $2019, \mathrm{PM}_{2.5}$ emissions decreased Whereas the changes of $\mathrm{PM}_{2.5}$ were statistically insignificant in rural zones (overall means of $6 \mu \mathrm{g} \mathrm{m}^{-3}$ vs. $\left.7 \mu \mathrm{g} \mathrm{m}^{-3}\right)$, the highest differences were observed in suburban $\left(10 \mu \mathrm{g} \mathrm{m}^{-3} \mathrm{vs.} 16 \mu \mathrm{g} \mathrm{m}^{-3}\right.$ in 2019$)$, and urban zones $\left(8 \mu \mathrm{g} \mathrm{m}^{-3}\right.$ vs. $\left.10 \mu \mathrm{g} \mathrm{m}^{-3}\right)$, being especially substantial for North $(49 \%)$ and Lisbon TV region $(\sim 30 \%)$. In metropolitan areas, large portion of $\mathrm{PM}_{2.5}$ is mostly secondary origin ${ }^{48}$ and the atmospheric conditions might impact formation of secondary PM even if emissions of precursors are reduced ${ }^{44}$. In state-of-the-art study, Querol et al. assessed anomalies in pollutant concentrations across in 11 metropolitan areas of Spain ${ }^{44}$ and also estimated the meteorology-normalized change of several pollutants before, during and after the 2020 lockdown. The work clearly demonstrated the importance of the association between pollution changes and meteorology. In terms of $\mathrm{PM}_{2.5}$ the authors emphasized the potential relevance of non-vehicular regional emissions on secondary PM precursors or other emission sources such as industry, agriculture/farming. While the data for urban traffic zones in this work are limited for $\mathrm{PM}_{2.5}$ (Supplementary Fig. 8S), in agreement with the previous results, April was the month with the lowest concentrations. Similar to 2019, in 2020 the overall mean of $\mathrm{PM}_{2.5}$ was below the annual target. Fifty-one exceedances of the annual limited were registered over the 5 months in 2020 (vs. 98 exceedances in 2019, i.e., $48 \%$ less than in 2019), all of them occurring in winter months, i.e., before the restrictions were enforced, $77 \%$ in January, 22\% in February.

Gaseous pollutants. For the gaseous pollutants the overall means of $\mathrm{NO}_{2}$ concentrations in 2019 (Fig. 1c) were $12 \mu \mathrm{g} \mathrm{m}^{-3}$ (range of Azores $3 \mu \mathrm{g} \mathrm{m}^{-3}$ - North 16) for rural zones, $42 \mu \mathrm{g} \mathrm{m}^{-3}$ for suburban $\left(33 \mu \mathrm{g} \mathrm{m}^{-3}\right.$ in Centre to $64 \mu \mathrm{g} \mathrm{m}^{-3}$ in North) and $54 \mu \mathrm{g} \mathrm{m}^{-3}\left(37 \mu \mathrm{g} \mathrm{m}^{-3}\right.$ in Algarve- $74 \mu \mathrm{g} \mathrm{m}^{-3}$ in North) for urban zones. These results show the strong impact of anthropogenic emissions of level of $\mathrm{NO}_{2}$, being typically considered as indicator of traffic emissions ${ }^{49,50}$. On European level, approximately $40 \%$ of NOx emissions are contributed by road transport sector ${ }^{27}$. The population exposure to ambient $\mathrm{NO}_{2}$ concentrations is especially relevant in urban areas because its emissions are close to the ground and are distributed across densely populated areas. Furthermore, the highest concentrations of $\mathrm{NO}_{2}$ were observed in suburban and urban zones of North region (i.e. $40 \%$ of coverage for traffic emissions monitoring in Portugal; Table 1). Concerning the limits for heath protection, 9 exceedances of hourly limit value in 2019 were registered in 5.9\% (4 stations) of all monitoring station (North and Lisbon TV region), all of them being urban sites (and 3 traffic influence).

In 2020, the means of $\mathrm{NO}_{2}$ concentrations at rural zones (Fig. 1c) were between $2 \mu \mathrm{g} \mathrm{m}^{-3}$ (Algarve) and $10 \mu \mathrm{g} \mathrm{m}^{-3}$ (North). In suburban zones, depending on each region the respective levels were 3-7 times higher, with means between $14 \mu \mathrm{g} \mathrm{m}^{-3}$ in Alentejo and $64 \mu \mathrm{g} \mathrm{m}^{-3}$ in North, whereas in urban zones the respective $\mathrm{NO}_{2}$ levels were even higher (4-18 times compared with rural zones) with range of $29-53 \mu \mathrm{g} \mathrm{m}^{-3}$ in Algarve and North, respectively. In agreement with the previous year, the highest levels of $\mathrm{NO}_{2}$ (up to 6 times) were observed for the zones (all) of North region. However, in $2020 \mathrm{NO}_{2}$ levels were significantly $(p<0.05)$ lower compared with the previous year, being approximately half for the rural and $30 \%$ lower in suburban and urban zones as follows, overall mean $6 \mu \mathrm{g} \mathrm{m}^{-3}$ vs. 12 for rural zones, $33 \mu \mathrm{g} \mathrm{m} \mathrm{m}^{-3}$ vs. $43 \mu \mathrm{g} \mathrm{m}^{-3}$ in suburban and $43 \mu \mathrm{g} \mathrm{m}^{-3} \mathrm{vs.} 56 \mu \mathrm{g} \mathrm{m} \mathrm{m}^{-3}$ in urban ones. Thus in 2020, $\mathrm{NO}_{2}$ pollution was significantly lower $(p<0.05)$ in all types of zones and in all regions of Portugal. $\mathrm{NO}_{2}$ was the pollutant with more significant changes during the two year and the restrictions associated with the COVID-19 pandemic seemed to have significant implications for relevant $\mathrm{NO}_{2}$ emission sources thus influencing its levels in air, both on local (direct) and regional level ${ }^{43}$, which might be the cause for lower concentrations of the pollutant observed at rural sites in 2020. In addition to $\mathrm{NO}_{2}$ emission sources and transport to other locations, chemical transformations of $\mathrm{NO}_{2}$ influence its ambient concentrations. After few hours in the air and in the presence of volatile organic compounds (VOCs) $\mathrm{NO}$ may be converted to $\mathrm{NO}_{2}$; with sunlight $\mathrm{NO}_{2}$ can convert back to $\mathrm{NO}$ and produce ozone ${ }^{51}$. Finally, meteorological conditions and surface deposition are the parameters that contribute to the temporal trends of ambient $\mathrm{NO}_{2}$ concentrations; March-May of 2020 was extremely warm period of year (meteorological parameters are summarized in Supplementary Table 6S), with an average temperature of $15.1{ }^{\circ} \mathrm{C}$ and several heat waves ${ }^{52}$, which could contribute to the respective levels. Concerning the urban traffic zones specifically (Fig. 2c), the concentrations of $\mathrm{NO}_{2}$ were lower than in the previous year in all regions between February and May, which might be due the annual trends. In the recent work Gama et al. ${ }^{43}$ assessed the air pollution trends $\left(\mathrm{NO}_{2}\right.$ and $\left.\mathrm{PM}_{10}\right)$ during last five years (2015-2020) in Portugal, selecting approximately only half of the existent monitoring stations (34 sites) Similarly to this work, authors reported a significant drop (41\%) of $\mathrm{NO}_{2}$ levels during the pandemic, with major changes at sites influenced by traffic. As shown in Fig. 2c significant decrease of $\mathrm{NO}_{2}$ levels at traffic sites was registered in March, April was then the month with the minimal means in 2020 in all the regions (range $17-33 \mu \mathrm{g} \mathrm{m}^{-3}$ ). Considering different regions, it is noteworthy that in North the $\mathrm{NO}_{2}$ levels were still almost twice higher (mean of $57 \mu \mathrm{g} \mathrm{m}^{-3}$ ) during 
the state emergency period than in the rest of country. In addition, evaluating then decrease of $\mathrm{NO}_{2}$ (Fig. 2d), the biggest changes between the two years were observed in March and April of 2020 when $\mathrm{NO}_{2}$ decreased by $15 \%$ (North) and $71 \%$ (Algarve). Considering the two largest and most populated urban areas in country (Lisbon MA and Oporto MA in Lisbon TV and North region, respectively; Supplementary Table $1 \mathrm{~S}$ ), $\mathrm{NO}_{2}$ cumulative decrease was $55 \%$ (40 and $15 \%$, respectively) which from the national perspective may represent several health benefits ${ }^{53}$. These results clearly confirm that $\mathrm{NO}_{2}$ levels were significantly lowered during restrictions associated COVID-19 outbreak (especially in months of March and April). Finally, in 2020 over the period analysed in this work all monitoring stations fulfilled the limit value for the health protection and no exceedances were observed, unlike the previous year.

$\mathrm{SO}_{2}$ (Fig. 1d) maximum of $1 \mathrm{~h}$ mean concentrations ranged between 2 and $12 \mu \mathrm{g} \mathrm{m}^{-3}$ in rural zones, 3-13 $\mu \mathrm{g} \mathrm{m}^{-3}$ and 3-29 $\mu \mathrm{g} \mathrm{m}^{-3}$ in suburban and urban zones, respectively. The levels of $\mathrm{SO}_{2}$ were especially high in North region, where for suburban and urban zones concentrations were 3-6 times higher than in the other regions. However, across all monitoring stations, $1 \mathrm{~h}$ limit alert threshold $\left(500 \mu \mathrm{g} \mathrm{m}^{-3}\right)$ and $1 \mathrm{~h}$ limits value $\left(350 \mu \mathrm{g} \mathrm{m}^{-3}\right)$ of $\mathrm{SO}_{2}$ concentrations were fulfilled. In addition, in general $\mathrm{SO}_{2}$ levels were below the $24 \mathrm{~h} \mathrm{limit}$ value; in 2019 only 3 stations (North region) registered $1 \mathrm{~h}$ maximum concentrations above the daily limit value, but the $24 \mathrm{~h}$ concentrations during those exceedances were fulfilled. In 2020 (Fig. 1d) the $1 \mathrm{~h}$ maximum means of $\mathrm{SO}_{2}$ were $5 \mu \mathrm{g} \mathrm{m}^{-3}$ (range of $1-10 \mu \mathrm{g} \mathrm{m}^{-3}$ ) in rural zones, and $9 \mu \mathrm{g} \mathrm{m}^{-3}\left(3-23 \mu \mathrm{g} \mathrm{m}^{-3}\right.$ ) and $10 \mu \mathrm{g} \mathrm{m}^{-3}$ (5-18 $\mu \mathrm{g} \mathrm{m}^{-3}$ ) in suburban and urban zones, respectively. For all three types of zones, the highest $\mathrm{SO}_{2}$ were observed in North region (up to 6 times for suburban zones and 9 times for urban ones) than in other regions. The North region was also the only one where $1 \mathrm{~h}$ maximum concentrations exceeded once the $24 \mathrm{~h}$ limit value (on urban industrial site). Finally, $1 \mathrm{~h}$ alert and $1 \mathrm{~h} \mathrm{limit}$ was obliged in all 68 monitoring stations. Though $\mathrm{SO}_{2}$ is a not a pollutant associated with traffic emissions, in 2020 the overall levels were approximately $65 \%$ lower than in the period of the previous year with overall means of $5 \mathrm{vs} .8 \mu \mathrm{g} \mathrm{m}{ }^{-3}$ which could be due to suspended industrial emissions. Nevertheless, evaluating the industrial sites specifically (suburban and urban Table 1), the means obtained between both years were not significantly different ( $6.3 \mathrm{vs} .6 .9 \mu \mathrm{g} \mathrm{m}^{-3}$ in 2019 ). In addition, the monthly evolution trend did not show any change of patterns in the lock down period, however, assessment of $24 \mathrm{~h}$ means (oppose to 1 maximum used in this work) should be conducted when available.

Data for ozone in 2019 (Fig. 1e) that maximum $1 \mathrm{~h}$ mean ranged between $74 \mu_{\mathrm{g} \mathrm{m}}^{-3}$ (North) and $104 \mu \mathrm{g} \mathrm{m}^{-3}$ (Algarve) of rural zones, $62 \mu \mathrm{g} \mathrm{m}^{-3}$ (North) and $90 \mu \mathrm{g} \mathrm{m}^{-3}$ (Alentejo) in suburban and $67 \mu \mathrm{g} \mathrm{m}^{-3}$ (North) and $101 \mu \mathrm{g} \mathrm{m}^{-3}$ (Algarve) in urban ones. These results show that registered $1 \mathrm{~h}$ maxima concentrations were higher $(p<0.05)$ at rural sites than those in suburban and urban ones, in agreement with other studies ${ }^{54}$ Production of background ozone exhibits both long-term trends and substantial annual variability ${ }^{55}$ also due to the variations in air-flow, air pressure or temperature ${ }^{56-58}$. In addition, ozone episodes are strongly influenced by meteorological conditions. The activation of photochemical reactions and efficient transport mechanisms for precursor emissions from upwind regions ideally occurs under anticyclonic conditions (i.e., the absence of cloud cover, high solar radiation, and more frequent warm temperatures ${ }^{44}$. Transport of ozone precursors and atmospheric chemical processes ${ }^{59}$ have strong impacts for ozone levels at rural zones. Firstly, $\mathrm{NO}_{2}$ has a longer lifespan in atmosphere (hours to days) ${ }^{51}$ than NO, which allows it to be transported over larger distances to rural areas, leading to $\mathrm{NO}_{2}$-based ozone formations ${ }^{54}$. Secondly, the lesser amount of $\mathrm{NO}$ in the atmosphere at rural sites (because of less traffic) leads to less ozone degradation. In addition, presence of VOCs at rural sites (due to emissions from vegetations) allows further reactions with $\mathrm{NO}$ to form $\mathrm{NO}_{2}$ which can form even more ozone, leading to even higher ozone concentrations. For all zones, the registered $1 \mathrm{~h}$ maxima of ozone were the lowest in north of country, consistently increasing towards the south, being the highest ones in southern regions of country (Algarve and Alentejo for suburban zones, Fig. 1e). In agreement, the north is the coldest part of the country, and south being the warmest one with mean air temperature as the following, $13.8^{\circ} \mathrm{C}$ in North, $15.1^{\circ} \mathrm{C}$ for Centre, 16.8 Lisbon TV, $16.9^{\circ} \mathrm{C}$ in Alentejo and $17.0^{\circ} \mathrm{C}$ in Algarve ${ }^{60}$. From the legislative perspective, the European hourly alert of $180 \mu \mathrm{g} \mathrm{m}^{-3}$ was exceeded once (North regions), whereas $1 \mathrm{~h}$ information threshold of 180 was reached once in Lisbon TV region $\left(120 \mu \mathrm{g} \mathrm{m} \mathrm{m}^{-3}\right.$, expressed as daily $8 \mathrm{~h}$ mean) though could not be clearly assessed, once the continuous measurements of ozone are not public yet. Finally, in 2020 the overall levels of ozone slightly (though not significantly) increased ( $83 \mathrm{vs.} 80 \mu \mathrm{g} \mathrm{m}^{-3}$ ). The spring 2020 (Supplementary Table $6 \mathrm{~S}$ ), was considered as extremely warm one (mean temperature of $15.1^{\circ} \mathrm{C}$, total precipitation of $\left.240 \mathrm{~mm}\right)^{51}$ which might be conducive to ozone formation. One h maxima levels ranged between $79 \mu \mathrm{g} \mathrm{m}^{-3}$ (North) and $92 \mu \mathrm{g} \mathrm{m}^{-3}$ (Alentejo) in Continental Portugal whereas levels on islands were higher $\left(92-97 \mu \mathrm{g} \mathrm{m}^{-3}\right)$. In agreement with the previous year, suburban and urban sites of Continental Portugal exhibited, respectively, significantly lower concentrations of ozone as the following, 59-80 $\mu \mathrm{g} \mathrm{m}^{-3}$ (North and Alenetejo), and 70-80 $\mu \mathrm{g} \mathrm{m}^{-3}$ (Centre and Lisbon TV). However, no differences were observed between the levels during the two years, with the means of $87 \mu \mathrm{g} \mathrm{m}^{-3}$ vs. $89 \mu \mathrm{g} \mathrm{m}^{-3}$ in 2020 and 2019 in rural sites, $73 \mu \mathrm{g} \mathrm{m}^{-3} \mathrm{vs} .79 \mu \mathrm{g} \mathrm{m}^{-3}$ for suburban, and $85 \mu \mathrm{g} \mathrm{m}^{-3}$ (in both years) at urban zones. The European hourly alert of $240 \mu \mathrm{g} \mathrm{m}^{-3}$ was not exceeded in 2020.

\section{Conclusions}

This work assessed air pollution levels and trend during COVID-19 period in Portugal (January-May 2020) compared with the previous year. The issued lockdown of the country enforced by the Portuguese government resulted in some positive, yet non uniform, changes of air pollution. $\mathrm{NO}_{2}$ was the pollutant that showed the most consistent decrease all over the country and across all different zones of urbanizations, in accord with reduced transport. Considering that annually road transport causes between 184,00 and 242,000 premature deaths worldwide ${ }^{61,62}$ public health benefits from reduction of the respective emissions might be significant. Regarding particulate matter, the major decreases were observed in remote and urban zones, suburban areas were impacted to a lesser degree and most dominantly in terms of fine PM. Whereas improved air quality will 
persist in long-term is uncertain, nonetheless the restrictions of COVID-19 conducted on large scale and in many countries simultaneously will provide a unique opportunity to re-examine current air quality policies and possible recovery scenarios to for air pollution reduction on global level.

\section{Data availability}

The data to obtain the findings of this study were retrieved from publicly available QualAr database. The datasets analysed during the current study are available from the corresponding author on reasonable request.

Received: 20 April 2021; Accepted: 1 September 2021

Published online: 29 October 2021

\section{References}

1. World Health Organization. WHO Director-General's statement on IHR Emergency Committee on Novel Coronavirus (2019nCoV). (Accessed 12 Aug 2020); https://www.who.int/dg/speeches/detail/who-director-general-s-statement-on-ihr-emergencycommittee-on-novel-coronavirus-(2019-ncov) (2020).

2. World Health Organization. Coronavirus disease (COVID-19) Situation Report-205. (Accessed 12 Mar 2021); https://www.who. int/docs/default-source/coronaviruse/situation-reports/20200812-covid-19-sitrep-205.pdf?sfvrsn=627c9aa8_2 (2020).

3. Zambrano-Monserrate, M. A., Ruano, M. \& Sanchez-Alcalde, L. Indirect effects of COVID-19 on the environment. Sci. Total Environ. 728, 138813. https://doi.org/10.1016/j.scitotenv.2020.138813 (2020).

4. Chakraborty, I. \& Maity, P. COVID-19 outbreak, migration, effects on society, global environment and prevention. Sci. Total Environ. 728, 138882. https://doi.org/10.1016/j.scitotenv.2020.138882 (2020).

5. Dutheil, F., Baker, J. S. \& Navel, V. COVID-19 and air pollution, the worst is yet to come. Environ. Sci. Pollut. Res. 27, 44647-44649. https://doi.org/10.1007/s11356-020-11075-6 (2020).

6. Saadat, S., Rawtani, D. \& Hussain, C. M. Environmental perspective of COVID-19 Exposure to air pollution and respiratory symptoms during the first 7 years of life in an Italian birth cohort. Sci. Total Environ. 728, 138870. https://doi.org/10.1016/j.scito tenv.2020.138870 (2020).

7. Arora, S., Bhaukhandi, K. D. \& Mishra, P. K. Coronavirus lockdown helped the environment to bounce back. Sci. Total Environ. 742, 140573. https://doi.org/10.1016/j.scitotenv.2020.140573 (2020).

8. Krecl, P., Targino, A. C., Oukawa, G. Y. \& Cassino, R. P. Drop in urban air pollution from COVID-19 pandemic, Policy implications for the megacity of São Paulo. Environ. Pollut. 265, 114883. https://doi.org/10.1016/j.envpol.2020.114883 (2020).

9. Siciliano, B., Dantas, G., da Silva, C. M. \& Arbilla, G. Increased ozone levels during the COVID-19 lockdown, analysis for the city of Rio de Janeiro, Brazil. Sci. Total Environ. 737, 139765. https://doi.org/10.1016/j.scitotenv.2020.139765 (2020).

10. Abdullah, S. et al. Air quality status during 2020 Malaysia Movement Control Order (MCO) due to 2019 novel coronavirus (2019nCoV) pandemic. Sci. Total Environ. 729, 139022. https://doi.org/10.1016/j.scitotenv.2020.139022 (2020).

11. Cui, Y. et al. Levels and sources of hourly PM2.5-related elements during the control period of the COVID-19 pandemic at a rural site between Beijing and Tianjin. Sci. Total Environ. 744, 140840. https://doi.org/10.1016/j.scitotenv.2020.140840 (2020).

12. Chu, B., Zhang, S., Liu, J., Ma, Q. \& He, H. Significant concurrent decrease in PM2.5 and $\mathrm{NO}_{2}$ concentrations in China during COVID-19 epidemic. J. Environ. Sci. 99, 346-353. https://doi.org/10.1016/j.jes.2020.06.031 (2021).

13. Latif, L. D., Dominick, D., Hawari, N. S. S., Mohtar, A. A. A. \& Othman, M. The concentration of major air pollutants during the movement control order due to the COVID-19 pandemic in the Klang Valley, Malaysia. Sustain. Cities Soc. 66, 102660. https:// doi.org/10.1016/j.scs.2020.102660 (2021).

14. Lian, X. et al. Impact of city lockdown on the air quality of COVID-19-hit of Wuhan city. Sci. Total Environ. 742, 140556. https:// doi.org/10.1016/j.scitotenv.2020.140556 (2020).

15. Kumar, P. et al. Temporary reduction in fine particulate matter due to 'anthropogenic emissions switch-off' during COVID-19 lockdown in Indian cities. Sustain. Cities Soc. 62, 102382. https://doi.org/10.1016/j.scs.2020.102382 (2020).

16. Shehzad, K., Sarfraz, M. \& Shah, S. G. M. The impact of COVID-19 as a necessary evil on air pollution in India during the lockdown. Environ. Pollut. 266, 115080. https://doi.org/10.1016/j.envpol.2020.115080 (2020).

17. Wang, Q. \& Su, M. A. A preliminary assessment of the impact of COVID-19 on environment-A case study of China. Sci. Total Environ. 728, 138915. https://doi.org/10.1016/j.scitotenv.2020.138915 (2020).

18. Rodríguez-Urrego, D. \& Rodríguez-Urrego, L. Air quality during the COVID-19, PM 2.5 analysis in the 50 most polluted capital cities in the world. Environ. Pollut. 266, 115042. https://doi.org/10.1016/j.envpol.2020.115042 (2020).

19. Pei, L. et al. Do air pollutants as well as meteorological factors impact Corona Virus Disease 2019 (COVID-19)? Evidence from China based on the geographical perspective. Environ. Sci. Pollut. Res. 27, 35584-35596. https://doi.org/10.1007/s11356-02112934-6 (2021).

20. Coccia, M. Effects of the spread of COVID-19 on public health of polluted cities, results of the first wave for explaining the dejà vu in the second wave of COVID-19 pandemic and epidemics of future vital agents. Environ. Sci. Pollut. Res. 28(15), 19147-19154. https://doi.org/10.1007/s11356-020-11662-7 (2021).

21. Briz-Redóna, A., Belenguer-Sapiña, C. \& Serrano-Arocac, S. Changes in air pollution during COVID-19 lockdown in Spain, A multi-city study. J. Environ. Sci. 101, 16-26. https://doi.org/10.1016/j.jes.2020.07.029 (2021).

22. Tobías, A. et al. Changes in air quality during the lockdown in Barcelona (Spain) one month into the SARS-CoV-2 epidemic. Sci. Total Environ. 726, 138540. https://doi.org/10.1016/j.scitotenv.2020.138540 (2020).

23. Collivignarelli, M. C. et al. Lockdown for CoViD-2019 in Milan, What are the effects on air quality?. Sci. Total Environ. 732, 139280. https://doi.org/10.1016/j.scitotenv.2020.139022 (2020).

24. QualAr The Monitoring Network (in Portuguese). (Accessed 27 Jul 2020); https://qualar.apambiente.pt/node/rede-de-medicaoda-qualidade-do-ar (2020).

25. Agência Portuguesa do Ambiente-APA. Ambient air. (Accessed 27 Jul 2020); https://apambiente.pt/index.php?ref=16\&subref= 82\&sub2ref=316 (2020).

26. QualAr. The observed pollution (in Portuguese). (Accessed 13 May - 30 June 2020); https://qualar.apambiente.pt/downloads, (2020).

27. European Environment Agency. Air quality in Europe 2019. EEA Report 10/2019. (European Environment Agency, 2019). (Accessed 7 Jun 2020); Air-quality-in-europe_2019-final_21102019.pdf

28. The Portugal News. President announces end of the state of emergency. The Portugal's National Newspaper in English (Accessed 27 Jul 2020); https://www.theportugalnews.com/news/president-announces-end-of-the-state-of-emergency/53920. Copyrights Anglopress Lda, The News Group of Newspaper agência. (2020).

29. Decreto-Lei 102/2010. Diário da República, 1. ${ }^{\text {a }}$ série - N. ${ }^{1} 186,4177-4205$ (2010) (in Portuguese).

30. Decreto-Lei 43/2015. Diário da República . $^{\circ} 61 / 2015,1711-1713$ (2015) (in Portuguesse).

31. Parliament, E. Directive 2008/50/EC of the European Parliament and of the Council on ambient air quality and cleaner air for Europe. Off. J. Eur. Union L152, 1-44 (2007). 
32. Brisa Concessão Rodoviária. FY 2019 Traffic Update. IRISA Concessão Rodoviária, S.A. (Accessed 5 June 2020); https://www. brisaconcessao.pt/Portals/0/comunicados/EN/BCR\%202019\%20Traffic\%20Update_v2.pdf, (2020).

33. Brisa Concessão Rodoviária. Resultados 2020. BRISA Concessão Rodoviária, S.A. (Accessed 1 Aug 2021); https://www.brisaconce ssao.pt/Portals/0/relat\%F3rios/BCR\%202020\%20Apres\%20Resultados\%20PT.pdf (2021) (in Portuguese).

34. International Transport Forum. Urban Mobility System Upgrade. Corporate Partnership Board Report. OECD/ITF (2015).

35. Statistics Portugal. Estatísticas dos Transportes e Comunicações 2018 (Instituto Nacional de Estatística, 2019) (in Portugesse).

36. Statistics Portugal. Mobilidade e funcionalidade do território nas Áreas Metropolitanas do Porto e de Lisboa, 2017 (Instituto Nacional de Estatística, 2018) (Accessed online 15 June 2020) (in Portugesse).

37. Ritchie, H. et al. Coronavirus Pandemic (COVID-19). Published at OurWorldInData.org. (Acessed 2 Aug 2021); https://ourwo rldindata.org/coronavirus (2020).

38. PORDATA. População residente, total e por grandes grupos etários (in Portuguese). (Accessed 28 Jul 2020); https://www.porda ta.pt/DB/Municipios/Ambiente+de+Consulta/Tabela (2020).

39. Fuertes, E. et al. A longitudinal analysis of associations between traffic-related air pollution with asthma, allergies and sensitization in the GINIplus and LISAplus birth cohorts. PeerJ 1, e193. https://doi.org/10.7717/peerj.193 (2013).

40. Ranzi, A. et al. Exposure to air pollution and respiratory symptoms during the first 7 years of life in an Italian birth cohort. Occup. Environ. Med. 71(6), 430-436. https://doi.org/10.1136/oemed-2013-101867 (2014).

41. Nieuwenhuijsen, M. J. \& Khreis, H. Car-free cities, pathways to healthy urban living. Environ. Int. 94, 251-262. https://doi.org/10. 1016/j.envint.2016.05.032 (2016).

42. Singh, V. et al. Diurnal and temporal changes in air pollution during COVID-19 strict lockdown over different regions of India. Environ. Pollut. 266(Pt 3), 115368. https://doi.org/10.1016/j.envpol.2020.115368 (2020).

43. Gama, C., Relvas, H., Lopes, M. \& Monteiro, A. The impact of COVID-19 on air quality levels in Portugal, A way to assess traffic contribution. Environ. Res. 193, 110515. https://doi.org/10.1016/j.envres.2020.110515 (2021).

44. Querol, X. et al. Lessons from the COVID-19 air pollution decrease in Spain, Now what?. Sci. Total Environ. 779, 146380. https:// doi.org/10.1016/j.scitotenv.2021.146380 (2021)

45. Conceição, R. et al. Saharan dust transport to Europe and its impact on photovoltaic performance, A case study of soiling in Portugal. Sol. Energy 160, 94-102. https://doi.org/10.1016/j.solener.2017.11.059 (2018).

46. Monteiro, A., Fernandes, A. P., Gama, C., Borrego, C. \& Tchepel, O. Assessing the mineral dust from North Africa over Portugal region using BSC-DREAM8b model. Atmos. Pollut. Res. 6(1), 70-81. https://doi.org/10.5094/APR.2015.009 (2015).

47. Health Effects Institute. State of Global Air 2019. Special Report. (Health Effects Institute, 2019).

48. Amato, F. et al. AIRUSE-LIFE+, a harmonized PM speciation and source apportionment in five southern European cities. Atmos. Chem. Phys. 16, 3289-3309. https://doi.org/10.5194/acp-16-3289-2016 (2016).

49. Frey, H. C. Trends in onroad transportation energy and emissions. J. Air Waste Manag. Assoc. 68(6), 514-563. https://doi.org/10. 1080/10962247.2018.1454357 (2018).

50. Hooftman, N., Messagie, M., Van Mierlo, J. \& Coosemans, T. A review of the European passenger car regulations-Real driving emissions vs local air quality. Sustain. Energy Rev. 86, 1-21. https://doi.org/10.1016/j.rser.2018.01.012 (2018).

51. Office of Research and Development - National Center for Environmental Assessment - RTP Division. Integrated science assessment for oxides of nitrogen-Health criteria. North Carolina, United States Environmental Protection Authority, EPA/600/R-15/068. (Accessed 11 Jul 2021); https://ofmpub.epa.gov/eims/eimscomm.getfile?p_download_id=526855 (2016).

52. Instituto Português do Mar e da Atmosfera. Boletim Climatológico Sazonal, Abril Primavera 2020. Instituto Português do Mar e da Atmosfera, I.P., Divisão de Clima e Alterações Climáticas, Lisbon, Portugal. https://www.ipma.pt/resources.www/docs/im.publi cacoes/edicoes.online/20200619/GwPEBFfpUDWyulJGBneX/cli_20200501_20200531_pcl_sz_co_pt.pdf (2020) (in Portuguese).

53. Khreis, H. et al. The health impacts of traffic-related exposures in urban areas, understanding real effects, underlying driving forces and co-producing future directions. J. Transp. Health 3(3), 249-267. https://doi.org/10.1016/j.jth.2016.07.002 (2016).

54. Jaff, D. A. et al. Scientific assessment of background ozone over the U.S., Implications for air quality management. Elementa 6(1), 56. https://doi.org/10.1525/elementa.309 (2018).

55. Lin, M., Horowitz, L. W., Payton, R., Fiore, A. M. \& Tonnesen, G. S. US surface ozone trends and extremes from 1980 to 2014, Quantifying the roles of rising Asian emissions, domestic controls, wild-fires, and climate. Atmos. Chem. Phys. 17, 2943-2970. https://doi.org/10.5194/acp-17-2943-2017 (2017).

56. Fiore, A. M., Naik, V. \& Leibensperger, E. M. Air quality and climate connections. J. Air Waste Manag. Assoc. 65(6), 645-685. https://doi.org/10.1080/10962247.2015.1040526 (2015).

57. Jaffe, D. A. \& Zhang, L. Meteorological anomalies lead to elevated $\mathrm{O}_{3}$ in the western US in June 2015. Geophys. Res. Lett. 44(4), 1990-1997. https://doi.org/10.1002/2016GL072010 (2017).

58. Shen, L. \& Mickley, L. J. Seasonal prediction of US summertime ozone using statistical analysis of large scale climate patterns. Proc. Natl. Acad. Sci. U.S.A. 114, 2491-2496. https://doi.org/10.1073/pnas.1610708114 (2017).

59. European Environment Agency. Greenhouse Gas Emissions from Transport in Europe (European Environment Agency, 2019).

60. Statistics Portugal. Average Temperatura of Air. Instituto Nacional de Estatística, Lisbon, Portugal. (Accessed 15 Jul 2020); https:// ine.pt $/$ xportal $/$ xmain? xpid=INE\&xpgid=ine_indicadores\&contecto=pi\&indOcorrCod=0008273\&selTab=tab0 (2020) (in Portuguesse).

61. Bhalla, K. et al. Transport for health, The Global burden of disease from motorized Road transport. World Bank Group, Washington, DC. (Accessed 30 Jul 2020). http://documents.worldbank.org/curated/en/2014/01/19308007/transport-health-global-burden-disea se-motorized-road-transport (2014).

62. Chambliss, S. E., Silva, R., West, J. J., Zeinali, M. \& Minjares, R. Estimating source-attributable health impacts of ambient fine particulate matter exposure, Global premature mortality from surface transportation emissions in 2005. Environ. Res. Lett. 9(10), 104009. https://doi.org/10.1088/1748-9326/9/10/104009 (2014).

\section{Acknowledgements}

This work was supported by Base Funding-UIDB/00511/2020 of the Laboratory for Process Engineering, Environment, Biotechnology and Energy_LEPABE, and by PCIF/SSO/0017/2018 funded by national funds through the FCT/MCTES (PIDDAC).

\section{Author contributions}

K.S.-Conceptualization, formal analysis data curation, critical revisions, writing-original draft; M.C.P.-Conceptualization, methodology, critical revision.

\section{Funding}

This work was supported by Base Funding-UIDB/00511/2020 of the Laboratory for Process Engineering, Environment, Biotechnology and Energy_LEPABE_-and by BioFirEx_PCIF/SSO/0017/2018 funded by national funds through the FCT/MCTES (PIDDAC). 


\section{Competing interests}

The authors declare no competing interests.

\section{Additional information}

Supplementary Information The online version contains supplementary material available at https://doi.org/ 10.1038/s41598-021-99491-7.

Correspondence and requests for materials should be addressed to K.S.

Reprints and permissions information is available at www.nature.com/reprints.

Publisher's note Springer Nature remains neutral with regard to jurisdictional claims in published maps and institutional affiliations.

(c) (1) Open Access This article is licensed under a Creative Commons Attribution 4.0 International License, which permits use, sharing, adaptation, distribution and reproduction in any medium or format, as long as you give appropriate credit to the original author(s) and the source, provide a link to the Creative Commons licence, and indicate if changes were made. The images or other third party material in this article are included in the article's Creative Commons licence, unless indicated otherwise in a credit line to the material. If material is not included in the article's Creative Commons licence and your intended use is not permitted by statutory regulation or exceeds the permitted use, you will need to obtain permission directly from the copyright holder. To view a copy of this licence, visit http://creativecommons.org/licenses/by/4.0/.

(C) The Author(s) 2021 